\title{
Capital Structure Shifts And Recession: An Empirical Investigation
}

Rakesh Duggal, Southeastern Louisiana University, USA

Michael Craig Budden, Southeastern Louisiana University, USA

\begin{abstract}
This study investigates whether the 2007-2009 recession impacted the capital structures of U.S. corporations. Investigating all non-financial firms in the $S \& P 500$ Index, the study finds that by boosting their book equity via dividend cuts and some debt reductions, firms kept book leverage unchanged.
\end{abstract}

Keywords: Capital Structure Shift; Capital Structure Theory; Corporate Financing Policy

\section{INTRODUCTION}

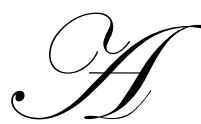

vast body of knowledge on the theory and practice of capital structure has emerged starting with Modigliani and Miller's (1958) formal theory of capital structure that postulates that there could not be a single optimal capital structure in perfect markets. They argue that, in the absence of market imperfections such as taxes, transaction costs, asymmetric information, agency costs, and bankruptcy costs, the firm's cost of capital is determined by the firm's investments and that it is not possible for a firm to lower its cost of capital by simply changing its debt-equity mix.

Researchers since Modigliani and Miller have concluded that market imperfections can and do create opportunities for the firm to lower its cost of capital by changing its capital structure mix. Tax deductibility of interest expense, for example, is a strong incentive for a firm to use debt in lieu of equity to lower the overall cost of capital. However, the existence of substantial bankruptcy costs deters managers from overusing debt. This results in an optimal capital structure according to the proponents of the trade-off theory, with firms employing a debtequity mix that minimizes overall cost of capital. The pecking order theory, on the other hand, uses information asymmetry to explain the managers' choice of a capital structure. According to this theory, managers will prefer borrowing to selling new equity for the fear that the sale of new equity will be perceived as a signal that the stock is overvalued. Thus, there is no optimal capital structure; however, the theory predicts a definitive managerial preference for internal funds, followed by debt and then new equity, in that order (Meyers and Majluf, 1984). Lastly, the market timing theory of capital structure argues that capital structure decisions are the cumulative outcomes of managers' attempts to time the equity market; managers will sell new equity in times of high valuations and buyback stock and/or borrow in times of low valuations (Baker and Wurgler, 2002). Levy and Hennessy (2007) arrive at the same conclusion as Baker and Wurgler by using the agency theory argument: Firms will use more debt during economic contractions to maintain managers' relative ownership and will use more equity during economic expansions.

In 2008, the world economies experienced one of the worst recessions in history. In the U.S., the recession officially started, according to the National Bureau of Economic Research, in December 2007 and ended in June 2009. The recession has hit financial firms the hardest, resulting in hundreds of bank failures. Although some nonfinancial firms declared bankruptcies, many who didn't resorted to layoffs, dividend cuts, and general business downsizing to survive. There is general consensus that many factors were responsible for this recession, including the Fed's expansionary monetary policy, lax corporate control, regulatory and rating agencies' failures, and excessive corporate leverage. It is generally conceded that many financial firms used excessive financial leverage prior to the recession. This study addresses the question of whether non-financial firms changed their financial leverage following the recession. There is anecdotal evidence that U.S. firms have been active in both the debt and 
equity markets to rebalance their capital structures. Two competing forces have been at work. First, due to the contraction in aggregate demand, firms had incentives to cut their fixed costs including interest expense and beef up their balance sheets by using more equity financing, including retained earnings. On the other hand, due to the quantitative easing by the Federal Reserve Bank resulting in historically low interest rates, firms found it very attractive to borrow.

This study computes multiple measures of corporate leverage at two time periods, December 2007, and December 2009, to determine any shifts in corporate financing policies as a result of the "great recession."

\section{LITERATURE REVIEW}

No single theory of capital structure is able to explain the cross-sectional and time series variances. Extant evidence suggests that leverage is related to profitability, market-to-book, firm size, asset tangibility, and industry leverage in a manner consistent with one or more of the capital structure theories discussed above. In general, studies have found evidence in support of the trade-off theory (Frank and Goyal; 2009), the market timing theory (Baker and Wurgler; 2002), the pecking order theory (Bharath, Pasqueriello, and Wu; 2009), and the agency theory (Levy and Hennessy; 2007). In addition Lemmon, Roberts, and Zender (2008) found that the above theories at best have limited power to explain the variation in corporate capital structures. Lemmon et al. found that corporate capital structures are stable over long periods of time and that firms that have high (low) leverage tend to remain so for over 20 years. Moreover, evidence suggests that firms do not appear to adjust their capital structures quickly.

\section{SAMPLE SELECTION AND STUDY DESIGN}

The study sample comprises all 419 non-financial firms that are part of the S\&P 500 Index. Financial firms are typically excluded in capital structure studies due to the regulated nature of their capital structures. Bloomberg data on the sample firms are used to perform analyses presented in this study.

This study tests to see whether the 2007-2009 recession encouraged managers to change corporate capital structures. Further tests are conducted to detect underlying shifts in the relative use of the three means of financing, retained earnings, new debt, and new equity. The predictions of the pecking order theory and the market timing theory are in the same direction. The recession caused severe across-the-board declines in stock prices. The S\&P 500 provided a negative return of approximately $39 \%$ in the calendar year 2008 . A recession and accompanying stock price declines may exacerbate asymmetric information so that managerial preference for retained earnings may be more pronounced. Therefore, a finding of greater use of retained earnings and/or debt following an economic contraction will be consistent with the pecking order theory. The average prime rate in 2009 fell to $3.25 \%$ from about $8 \%$ in 2007 and $5.2 \%$ in 2008 . Given a severe contraction in stock prices, the market timing theory predicts stock buybacks and/or greater use of debt to minimize the cost of capital. The trade-off theory's prediction, however, is ambiguous. The recession likely increased the potential bankruptcy costs for U.S. firms resulting in a shift away from debt. On the other hand, the reduction in borrowing rates increased the attractiveness of debt. A finding of no significant change in capital structures will be consistent with the previous findings of stable capital structures over time and/or slow adjustments.

Following Baker and Wurgler (2002), the following variable values are estimated for 2007 (pre-recession) and 2009 (post-recession) and $t$ tests are performed to see if the financial leverage changed from 2007 to 2009. Further tests are conducted to test the predictions of various theories discussed above. In particular, it is investigated whether changes in financial leverage are associated with any significant issue/buyback of stock/debt and changes in retained earnings.

Book equity $=$ Total assets - total liabilities - preferred stock + deferred taxes

Book leverage $=($ Total assets - book equity $) /$ Total assets

Market leverage $=($ Total assets - book equity $) /($ Total assets - book equity + market equity $)$

Market value/Book value $=($ Total assets - book equity + market equity $) /$ Total assets

Net equity issue $=($ Change in book equity - change in retained earnings $) /$ Total assets

Net retained earnings $=$ Change in retained earnings/Total assets

Net debt issue $=($ Change in total assets - change in book equity - change in retained earnings $) /$ Total assets 


\section{EVIDENCE}

As the mean value for the market to book ratio (a measure of available investment opportunities and relative valuation) indicates in Table 1, there was a highly significant contraction in stock prices in the 2007-2009 period. As a result market leverage rose significantly; however, there was no noticeable change in book leverage. This is due to the fact that while the market leverage measure is influenced greatly by the firm's stock price, the book value measure is affected by the accounting value of equity, including dividend changes (negative and highly significant) and change in retained earnings (positive and highly significant). It must be noted that both measures also reflect the impact of net debt issue (negative and marginally significant) and new equity issues (the sign is positive but insignificant). The data indicate that firms, when faced with a severe contraction in aggregate demand and the resulting lower cash flows, boosted their retained earnings by reducing dividend payments and debt obligations.

Table 1

Mean values for leverage-related variables for 2007 and 2009 and t-statistics for mean differences. The sample consists of 419 non-financial firms in the S\&P 500 Index.

\begin{tabular}{|l|c|c|c|}
\hline \multicolumn{1}{|c|}{ Variable } & $\begin{array}{c}\mathbf{2 0 0 7} \\
\text { Mean }\end{array}$ & $\begin{array}{c}\mathbf{2 0 0 9} \\
\text { Mean }\end{array}$ & $\begin{array}{c}\text { t-statistic for Mean } \\
\text { Difference(2009-2007) }\end{array}$ \\
\hline Market to Book & 2.29 & 1.88 & $-7.21^{* *}$ \\
\hline Book Leverage & 0.56 & 0.57 & 0.46 \\
\hline Market Leverage & 0.32 & 0.37 & $14.54^{* *}$ \\
\hline Book equity & $\$ 12,184$ million & $\$ 9,185$ million & -0.92 \\
\hline New Equity Issue & -0.25 & 0.01 & 1.03 \\
\hline Net Retained Earnings & 0.01 & 0.04 & $4.62^{* *}$ \\
\hline Dividend Payment & 0.03 & 0.02 & $-4.34^{* *}$ \\
\hline Net Debt Issue & 0.31 & -0.03 & $-1.34^{*}$ \\
\hline
\end{tabular}

*Significant at the $10 \%$ confidence level in a one-tailed test.

**Significant at the $5 \%$ confidence level.

The above evidence is in line with Lemmon, Roberts, and Zender (2008) who report stable corporate capital structures over long periods. The evidence is also consistent with the pecking order theory, which predicts that dividend decisions are 'residual' decisions in the sense that managers distribute the residual cash balance after exhausting their investment opportunities. The marginally significant change in net debt may indicate the presence of bankruptcy costs and the managers' desire to roll back their leverage. To summarize, to counter the shrinkage in book value of equity due to the recession, managers cut back on dividend payments and simultaneously reduced net debt. The cumulative effect of all of these changes was no change in the overall book leverage.

The data were segregated by industry to investigate whether the overall findings reported above are uniform across all nine industries represented in S\&P 500. As Table 2 indicates, market leverage rose significantly across all industries, while book leverage rose in three industries - materials, industrials, and consumer discretionary (marginal increase) - and marginally declined in utilities. The industries with increased book leverage were affected by the recession more than other industries and were unable to maintain their pre-recession leverage levels despite cuts in dividends and debt levels. There is also weak evidence of stock buybacks in the materials and industrials industries. The utilities industry was the only industry to reduce book leverage, although marginally, through a simultaneous issue of equity and reduction in dividends and debt. 
Table 2

Average change in leverage-related variables by industry from 2007 to 2009 . t-statistics for mean differences are presented in parentheses. The sample consists of 419 non-financial firms in the S\&P 500 Index.

\begin{tabular}{|c|c|c|c|c|c|c|}
\hline & $\begin{array}{c}\text { Book } \\
\text { Leverage }\end{array}$ & $\begin{array}{c}\text { Market } \\
\text { Leverage }\end{array}$ & $\begin{array}{c}\text { New equity } \\
\text { Issue }\end{array}$ & $\begin{array}{c}\text { New } \\
\text { Retained } \\
\text { Earnings }\end{array}$ & $\begin{array}{l}\text { Dividend } \\
\text { Payment }\end{array}$ & $\begin{array}{l}\text { New Debt } \\
\text { Issue }\end{array}$ \\
\hline Energy & $\begin{array}{l}-0.02 \\
(-0.84)\end{array}$ & $\begin{array}{c}0.08 \\
(6.01 * *)\end{array}$ & $\begin{array}{l}-0.01 \\
(-0.34)\end{array}$ & $\begin{array}{c}-0.05 \\
(-4.77 * *)\end{array}$ & $\begin{array}{c}-.01 \\
\left(-4.5^{* *}\right)\end{array}$ & $\begin{array}{c}0.01 \\
(0.57)\end{array}$ \\
\hline Materials & $\begin{array}{c}0.04 \\
\left(2.75^{* *}\right)\end{array}$ & $\begin{array}{c}0.07 \\
\left(5.95^{* *}\right)\end{array}$ & $\begin{array}{c}-0.03 \\
(-1.59 *)\end{array}$ & $\begin{array}{l}-0.012 \\
(-0.89)\end{array}$ & $\begin{array}{c}-0.01 \\
(-1.47 *)\end{array}$ & $\begin{array}{l}-0.03 \\
(-0.97)\end{array}$ \\
\hline Industrials & $\begin{array}{c}0.03 \\
\left(2.49^{* *}\right) \\
\end{array}$ & $\begin{array}{c}0.08 \\
(9.18 * *)\end{array}$ & $\begin{array}{c}-0.01 \\
(-1.70 *) \\
\end{array}$ & $\begin{array}{c}0.01 \\
(0.82)\end{array}$ & $\begin{array}{c}-0.01 \\
(-2.26 * *)\end{array}$ & $\begin{array}{c}-0.08 \\
(-3.97) \\
\end{array}$ \\
\hline $\begin{array}{l}\text { Consumer } \\
\text { Discretionary }\end{array}$ & $\begin{array}{c}0.02 \\
(1.61 *)\end{array}$ & $\begin{array}{c}0.04 \\
(3.98 * *)\end{array}$ & $\begin{array}{l}-0.01 \\
(-0.42)\end{array}$ & $\begin{array}{c}0.07 \\
\left(4.30^{* *}\right)\end{array}$ & $\begin{array}{c}-0.01 \\
(-2.47)\end{array}$ & $\begin{array}{c}-0.12 \\
(-4.74 * *)\end{array}$ \\
\hline $\begin{array}{l}\text { Consumer } \\
\text { Staples }\end{array}$ & $\begin{array}{c}0.04 \\
(1.25)\end{array}$ & $\begin{array}{c}0.06 \\
(3.90 * *)\end{array}$ & $\begin{array}{c}2.62 \\
(1.02)\end{array}$ & $\begin{array}{c}0.03 \\
(1.62 *)\end{array}$ & $\begin{array}{l}-0.00 \\
(-0.33)\end{array}$ & $\begin{array}{l}-2.67 \\
(-1.05)\end{array}$ \\
\hline Healthcare & $\begin{array}{c}0.03 \\
(1.17)\end{array}$ & $\begin{array}{c}0.08 \\
(5.04 * *)\end{array}$ & $\begin{array}{c}0.02 \\
\left(1.35^{*}\right) \\
\end{array}$ & $\begin{array}{c}0.01 \\
(0.43) \\
\end{array}$ & $\begin{array}{c}-0.01 \\
(-3.24 * *)\end{array}$ & $\begin{array}{c}-0.04 \\
(-1.50 *) \\
\end{array}$ \\
\hline $\begin{array}{l}\text { Information } \\
\text { Technology }\end{array}$ & $\begin{array}{c}-0.01 \\
(-0.50)\end{array}$ & $\begin{array}{c}0.03 \\
(3.72 * *)\end{array}$ & $\begin{array}{l}-0.01 \\
(-0.82)\end{array}$ & $\begin{array}{c}0.09 \\
\left(3.95^{* *}\right)\end{array}$ & $\begin{array}{c}-0.00 \\
(-1.34 *)\end{array}$ & $\begin{array}{c}-0.14 \\
(-4.03 * *)\end{array}$ \\
\hline $\begin{array}{l}\text { Telecommunication } \\
\text { Services }\end{array}$ & $\begin{array}{c}0.04 \\
(0.91)\end{array}$ & $\begin{array}{c}0.13 \\
(4.32 * *)\end{array}$ & $\begin{array}{c}0.06 \\
(1.08)\end{array}$ & $\begin{array}{c}0.06 \\
(0.95)\end{array}$ & $\begin{array}{c}-0.00 \\
(-0.41)\end{array}$ & $\begin{array}{l}-0.06 \\
(-0.64)\end{array}$ \\
\hline Utilities & $\begin{array}{c}-0.01 \\
\left(-1.36^{*}\right) \\
\end{array}$ & $\begin{array}{c}0.07 \\
(7.72 * *) \\
\end{array}$ & $\begin{array}{c}0.02 \\
(1.91 * *) \\
\end{array}$ & $\begin{array}{c}0.01 \\
(1.17) \\
\end{array}$ & $\begin{array}{c}-0.01 \\
(-5.92 * *) \\
\end{array}$ & $\begin{array}{c}-0.04 \\
(-1.91 * *) \\
\end{array}$ \\
\hline
\end{tabular}

*Significant at the $10 \%$ confidence level in a one-tailed test.

$* *$ Significant at the $5 \%$ confidence level.

\section{SUMMARY AND CONCLUSION}

This study investigated whether the 2007-2009 recession caused a significant shift in corporate leverage. Examining the 419 non-financial firms comprising the S\&P 500 Index, indicates a significant increase in market leverage due to stock price declines but no significant shift in book leverage. Corporations in general were able to maintain their pre-recession level of book leverage by offsetting the reduced book value of equity due to the recession-induced losses with reduced dividends and debt levels. This evidence shows that managers actively manage their capital structures. It is conjectured that the above managerial actions and higher stock prices over time will likely restore the pre-recession level of market leverage.

\section{AUTHOR INFORMATION}

Dr. Rakesh Duggal is LaBorde Professor of Finance at Southeastern Louisiana University. His research interests include corporate governance, capital structure, institutional investors and cost of capital. E-mail: rduggal@ selu.edu

Dr. Michael Craig Budden is Professor of Marketing and Faculty Ombudsperson at Southeastern. His research interests include intellectual property protection, ethics, marketing strategy and commercial law. E-mail: mbudden@selu.edu

\section{REFERENCES}

1. Baker, M and J. Wurgler, 2002, "Market timing and capital structure," Journal of Finance, 57 (1), 1-32.

2. Bharat T., P. Pasquariello, and G. Wu, 2009, "Does asymmetric information drive capital structure decisions?” Review of Financial Studies, 22 (8), 3211-3243.

3. Frank, Murray Z., and V. K. Goyal, 2009, "Capital structure decisions: Which factors are reliably important?" Financial Management, 38 (1), 1-37. 
4. Lemmon, M., M. Roberts, and J. Zender, 2008, "Back to the Beginning: Persistence and the Cross-section of the Corporate Capital Structure," Journal of Finance, 48 (4), 575-1609.

5. Levy, A, and C. Hennessy, 2007, "Why does capital structure choice vary with macroeconomic conditions," Journal of Monetary Economics, 54 (6), 1545-1564.

6. Meyers, S. and N. Majluf, 1984, "Corporate financing and investment decisions when firms have information that investors do not have," Journal of Financial Economics, 13 (2), 187-221.

7. Modigliani, F., and M. Miller, 1958, "The cost of capital, corporate finance, and the theory of investment," American Economic Review, June, 261-297. 


\section{NOTES}

